Julie Grob

\title{
RBMS, SPECIAL COLLECTIONS, AND THE CHALLENGE OF DIVERSITY: THE ROAD TO THE DIVERSITY ACTION PLAN
}

ANYONE WHO HAS EVER ATTENDED an RBMS preconference will have noticed the racial and ethnic homogeneity among the section's members. In 1997, a survey in the RBMS newsletter revealed that 97 percent of RBMS members were white. ${ }^{1}$ Historically, RBMS has responded to the challenge of increasing diversity with some talk, but little action. The recent approval by the RBMS executive board of the Diversity Action Plan is a positive and long overdue step toward encouraging more diversity in the section.

Making an effort to attract more members of underrepresented racial and ethnic groups to RBMS is the right thing to do and critical if we are to remain forward-looking and vibrant as an organization. As the sole body for special collections librarians within the ALA, we should be leading the effort to encourage diversity in our branch of the profession, rather than hoping the problem will solve itself. Increasing the diversity of our members should be a top priority for RBMS and an activity that is thoroughly integrated throughout the organization from the agenda of the executive committee to the preconference experiences of individual members.

In order to reflect properly our changing society, meet the needs of an increasingly diverse patron base, identify and preserve materials

1. "RBMS Membership Survey," RBMS Newsletter 26 (Spring 1997), completed forms are held by RBMS Membership and Professional Development Committee. 
from a wide range of cultures, and respond to changing trends in scholarship, we need more special collections professionals with varied racial and ethnic backgrounds. As our libraries increasingly seek collections focused on particular racial and ethnic groups, we must develop a pool of librarians with the appropriate language skills and cultural knowledge to best serve these collections. Although librarians from particular racial and ethnic groups may have a special interest or expertise in working with the materials of that group, ideally, people should be encouraged to work with the materials that engage them most, regardless of their background. Finally, because our profession is involved in selecting materials to be preserved for the future, we should ensure that we have as diverse a group of people involved in the acquisition of rare books and manuscript collections as possible.

The following pages compare our organization's racial and ethnic makeup to that of the rest of the profession and the country, detail the ways in which diversity has (and has not) been addressed throughout RBMS' history, examine how activities in recent years have led to the creation of the RBMS Task Force on Diversity, and present a condensed version of the new Diversity Action Plan. Because the work of special collections librarians is so closely intertwined with the development of collections, this article also explores the growth of traditional and ethnic collections during the nineteenth and twentieth centuries. By better understanding our past, we can more wisely position ourselves to meet the challenges of the future.

\section{Diversity and Librarianship}

RBMS and the special collections librarians who comprise its membership lag well behind the rest of the library profession in diversity. Statistics show that the section's members are far more homogeneous than academic librarians in general. A 1998 ALA survey of academic 
librarians found that 87 percent were white, 6 percent were African American, 2 percent were Hispanic, 5 percent were Asian American, and less than 1 percent were American Indian or Alaskan Native. ${ }^{2}$ These figures show that the percentage of people from underrepresented racial and ethnic groups is four times greater among academic librarians than among RBMS members.

The demographics for other types of librarians break down along similar lines. Although conventional wisdom says that more librarians of color are attracted to working in public and school libraries than in academic libraries, ALA statistics do not bear this out. A pair of 1998 surveys revealed that 87 percent of public librarians and 90 percent of school librarians were white. ${ }^{3}$ College and university faculty members are also strikingly similar to academic librarians in racial and ethnic makeup. According to 1999 statistics from the Department of Education, 86 percent of faculty members were white, 5 percent were black, 3 percent were Hispanic, 5 percent were Asian or Pacific Islander, and less than 1 percent were American Indian or Alaskan Native. ${ }^{4}$

Although librarians in general exhibit far greater diversity than RBMS members, the profession as a whole is still struggling to reflect the makeup of the current population of America. The 2000 census indicates that 75 percent of Americans are white, 12 percent are black or African American, 12 percent are of Hispanic or Latino origin, 3.5 percent are Asian, 1 percent are American Indian, and 0.1 percent are Native Hawaiians or Pacific Islanders. About 2.5 percent of Americans

2. Mary Jo Lynch, "Racial and Ethnic Diversity Among Librarians: A Status Report," ALA. Available online from http://www.ala.org/Content/NavigationMenu/Our_Association/Offices/ Human_Resource_Development_and_Recruitment/Library_Employment_Resources/ Racial_and_Ethnic_Diversity_Among_Librarians_(1998).htm.

3. Ibid.

4. National Center for Education Statistics, "Chapter 3. Postsecondary Education," Digest of Education Statistics, 2002. Available online from http://nces.ed.gov/pubs2003/digest02/index.asp. 
consider themselves multiracial. ${ }^{5}$ About 25 percent of the American population belongs to a race other than white, but among academic librarians only 13 percent are a race other than white, and among RBMS members only 3 percent are a race other than white. ${ }^{6}$

\section{Exclusivity and Diversity in Special Collections}

Special collections librarians face a particularly strong challenge in attracting members of underrepresented groups to our profession, partly due to the ongoing perception that we are exclusive and elitist. Looking back, we can find the origin of these attitudes in the history of book collecting and libraries. Book collecting experienced a "golden age" in America in the late nineteenth and early twentieth centuries, when some extraordinarily wealthy Americans were able to purchase the contents of important British and American private libraries. The libraries built by collectors during this period would become the foundations of major rare book collections at universities, as the libraries of men such as Harry Elkins Widener and William L. Clements were donated to Harvard and the University of Michigan in 1915 and 1923, respectively. ${ }^{7}$

American book collectors of this period were mainly well-educated businessmen or professional men with ties to the Northeast. Their private libraries were indicators of their social standing and refinement. "Books, both knowledge, writing about books, and participating in a

5. U.S. Census Bureau, Population Division, "Population by Race and Hispanic or Latino Origin for the United States: 1990 and 2000 (PHC-T-1)." Available online from http://www.census.gov/ population/www/cen2000/phc-t1.html. Two major changes were made to the race question on the 2000 census. For the first time, the census form allowed respondents of mixed race to choose more than one category so that they no longer had to limit themselves to indicating a single race. In addition, the form treated Hispanic or Latino ethnicity as a separate category because Hispanic origin is more accurately considered an ethnicity than a race. On the 2000 census form, Hispanics could indicate that they were Hispanic and white, Hispanic and black, or some other combination. For the sake of comparison with other surveys, the figure for Hispanic or Latino origin will be given in this article alongside the figures for race. The resulting percentages add up to greater than 100 percent, with most of the overlap being between the white and Hispanic categories.

6. In this instance, the term race is intended to encompass Hispanic ethnicity.

7. "The History of Widener Library," Widener Library, Harvard University. Available online from http://hcl.harvard.edu/widener/about/history.html. Robert A. Shaddy, Books and Book Collecting in America, 1890-1930 (Lewiston: E. Mellen Press, 2000), 118. 
sub-culture of book collecting allowed these Victorians to achieve and reflect genteel status." ${ }^{8}$ In 1858, Oliver Wendell Holmes extolled the "man of family" who was steeped in tradition and comfortable among books. "Above all things, as a child, he should have tumbled about in a library. All men are afraid of books, who have not handled them from infancy ... He is at home wherever he smells the invigorating fragrance of Russian leather. No self-made man feels so." 9

The elite American collector of this period followed "comfortable literary and aesthetic traditions," guided on his quest "by English signposts some two centuries old." ${ }^{10} \mathrm{He}$ saw himself as a "custodian of culture," following in the tradition of the great bookmen before him. ${ }^{11}$ Voracious collector Henry Huntington began in the 1910s to focus his interest on Anglo-American books, with an eye toward building an institution where Americans could study their own historical and literary antecedents. ${ }^{12}$ Henry Clay Folger was said to have similar desires in founding the Folger Shakespeare Library: "He envisioned the cultural value, the ethical and social value of the beauty and idealism of Shakespeare ... one of the wells from which we Americans draw our national thought, our faith and our hope." ${ }^{13}$ In their collecting and in their philanthropy, men such as Huntington and Folger were preserving and maintaining the Anglo-American culture in which they had thrived.

The university libraries that received rare book collections created special rooms to house them that incorporated the sumptuous furniture and wood-paneled walls of a gentleman's library. The Treasure Room in

8. Shaddy, Books and Book Collecting, 18.

9. Oliver Wendell Holmes, "Chapter 1," in The Autocrat of the Breakfast-Table. Available online from http://www.worldwideschool.org/library/books/lit/humor/TheAutocratoftheBreakfast-table/ chap1.html.

10. Frederick B. Adams, Jr., "Introduction" in Book Collecting: A Modern Guide, ed. Jean Peters (New York: R.R. Bowker, 1977), xi.

11. Shaddy, Books and Book Collecting, 18.

12. Louis B. Wright, "Huntington and Folger: Book Collectors with a Purpose," Atlantic Monthly 209, no. 4 (April 1962): 71.

13. "History," Folger Shakespeare Library. Available online from http://www.folger.edu/intro/history.asp. 
the Doheny Memorial Library of the University of Southern California included "a frieze of murals ... on the history of the written word" and wainscoting and bookcases of imported English oak. ${ }^{14}$ In the words of William L. Joyce, "Though the artifacts collected might be 'treasured' as source material for scholarly research, no doubt their financial valuenot to say prestige value or elitism-was also duly recognized."15

Outside this privileged world, a small, but significant, number of African American bibliophiles also were amassing book collections. Centered in northeastern cities such as Philadelphia and Washington D.C., early African-American collectors such as Robert Mara Adger ${ }^{16}$ and Henry Proctor Slaughter ${ }^{17}$ were motivated by different impulses than those of their white counterparts. "They collected books to counter the pseudoscientific racism that was so prevalent during that time, when so-called scholars and writers were claiming that black people were by nature inferior, that a black person could not be found who could comprehend geometry, that black people could memorize by rote but could not reason." Black bibliophiles sought to gather together evidence of the historical and cultural achievements of African Americans and of the long and illustrious record of the African civilization that was their heritage. ${ }^{18}$

African-American book collectors of later generations shared similar motivations, as Charles Blockson attests in his 1998 book Damn Rare: The Memoirs of an African-American Bibliophile. The Philadelphia collector traces his obsession with books to an incident that occurred in his

\footnotetext{
14. "Getting to Know Doheny Memorial Library Circa 1932," Doheny Memorial Library. Available online from http://www.usc.edu/isd/archives/la/pubart/USCArt/Doheny/HistTour/ main_floor.html.

15. William L. Joyce, "The Evolution of the Concept of Special Collections in American Research Libraries," Rare Books and Manuscripts Librarianship 3, no. 1 (Spring 1988): 25.

16. Tony Martin, "Bibliophiles, Activists, and Race Men," in Black Bibliophiles and Collectors: Preservers of Black History, ed. Elinor Des Verney Sinnette, W. Paul Coates, and Thomas C. Battle (Washington, D.C.: Howard University Press, 1990), 24-28.

17. Charles L. Blockson, Damn Rare: The Memoirs of an African-American Bibliophile (Tracy, Calif.: Quantum Leap Publisher, 1988), 231, 236.

18. Martin, "Bibliophiles, Activists, and Race Men," 29.
} 
fourth-grade history class in 1943. After a lecture on Benjamin Franklin, the young Blockson had asked his teacher about the contributions of African Americans. She replied, "Negroes have no history. They were born to serve white people." Confused and angry, Blockson set out to prove his teacher wrong by assembling a small collection of materials related to people of African descent. ${ }^{19}$ Forty years later, he had accumulated a collection of more than 20,000 books and documents, which he donated to Temple University in Philadelphia in $1984 .^{20}$

The late nineteenth- and early twentieth-century black bibliophiles also entrusted their collections to research libraries. The greatest of these, the Puerto Rican-born black collector Arturo Alfonso Schomburg, became interested in his roots as a young man in Puerto Rico after listening to fellow members of literary clubs extol the deeds of their white ancestors. ${ }^{21}$ His collection of 5,000 books, manuscripts, prints, and realia about blacks in America, Africa, and the Caribbean was purchased by the Carnegie Corporation in 1926, at the behest of the National Urban League, for the New York Public Library. ${ }^{22}$ The collections of other bookmen went to black universities. Jesse E. Moorland donated his collection of 1,500 books to Howard University in $1914,{ }^{23}$ and Henry Proctor Slaughter sold his collection to Atlanta University in $1946 .{ }^{24}$

Many of the great collections of African-American books went to Historically Black Colleges and Universities, also known as HBCUs. The HBCU designation applies to those institutions that were founded prior to the Civil Rights Act of 1964 specifically for the education of

19. Blockson, Damn Rare, xii-xiii.

20. Ibid., 301-2.

21. Elinor Des Verney Sinnette, "Arthur Alfonso Schomburg (1874-1938), Black Bibliophile and Collector," in Black Bibliophiles and Collectors, 37.

22. Casper LeRoy Jordan, "African American Forerunners in Librarianship," in Handbook of Blacke Librarianship, 2nd ed., ed. E. J. Josey and Marva L. DeLoach (Lanham, Md.: Scarecrow Press, 2000), 20.

23. "The Book Collections," Moorland-Spingarn Research Center, Howard University. Available online from http://www.founders.howard.edu/moorland-spingarn/ book.htm\#Moorland\%20Collection.

24. Jordan, "African American Forerunners," 21. 
blacks, and most are found in the South. ${ }^{25}$ Historically, HBCUs have been chronically underfunded, but vitally important in educating the black community, and their libraries housed the major repositories of African-American books and manuscripts in existence. "These black collections were revered products of the years, assembled without benefit of special monies or staff ... The collections were fostered by painstaking care, guided by knowledgeable curators and librarians ..."26

During the early twentieth century, universities began collecting rare materials related to the countries of origin of Latinos and Asian Americans. In 1921, the University of Texas at Austin purchased the private library of Mexican bibliophile Genaro Garcia. That collection formed the basis for what is now the Nettie Lee Benson Latin American Collection, an enormous research library that includes many rare books, manuscripts, maps, and photographs. ${ }^{27}$ At Berkeley, faculty member John Fryer deposited his private library of materials on China in 1896, setting in motion the creation of the East Asian Library. ${ }^{28}$ The focus of these and other area studies libraries was primarily foreign countries, however, and not the story of Americans of Hispanic or Asian descent.

Many universities also collected materials related to Native Americans, usually as part of larger Americana or Western collections. Prominent in these collections were the color plate books and glass plate negatives created by white artists and ethnographers to document Native Ameri-

25. Irene Owens, "Stories Told But Yet Unfinished: Challenges Facing African-American Libraries and Special Collections in Historically Black Colleges and Universities," in Diversity Now: People, Collections, and Services in Academic Libraries, ed. Teresa Y. Neely and Kuang-Hwei (Janet) Lee-Smeltzer (New York: Haworth Information Press, 2002), 167.

26. Ann Allen Shockley, Handbook of Black Librarianship, ed. E. J. Josey and Ann Allen Shockley (Littleton, Colo.: Libraries Unlimited, Inc., 1977), 183.

27. Philip A. Metzger, "Genaro Garcia Collection, Benson Latin American Collection, University of Texas at Austin," Libraries \& Culture, Bookplate Archive. Available online from http:// www.gslis.utexas.edu/ landc/bookplates/12_1_Garcia.htm, originally published in Journal of Library History 12, no. 1 (Winter 1977): 71-72.

28. About EAL, East Asian Library, University of California, Berkeley. Available online from http:// www.lib.berkeley.edu/EAL/about.html. 
cans. Beginning in 1958, Native American tribes began establishing their own libraries. ${ }^{29}$ Ten years later, the first tribal college, now known as Diné College, was created to serve students of the Navajo Nation. Many of the thirty-four tribal colleges and universities that are currently recognized by the federal government house tribal archives and collect oral histories of tribal elders. ${ }^{30}$

The impact of the civil rights movement of the 1960s on library collections and librarianship cannot be overemphasized. Sixties activism and the influence of Black Power and other ethnic pride movements led to the creation of ethnic studies programs on college campuses in the late 1960s, which in turn drove the demand for specialized resources to support the new curricula. Simultaneously, the sense of empowerment fostered by the civil rights movement and the growth in ethnic collections also led to the formation of numerous professional organizations for librarians from underrepresented racial and ethnic groups.

The nation's first black studies and first ethnic studies programs were created at San Francisco State University in 1969 in response to five acrimonious months of strikes by students and retaliation by administration. ${ }^{31}$ Attacking "the almost exclusive focus on Western culture and civilization ..., minority students complained justifiably that not only the curriculum, but support service mechanisms were unavailable to them." ${ }^{32}$ Under pressure, universities across the country increased the number of classes in the history of blacks and other racial and ethnic groups, and hired additional faculty from these underrepresented groups. During the

29. Lotsee Patterson, "History and Status of Native Americans in Librarianship," Library Trends 49, no. 1 (Summer 2000): 188.

30. American Indian Higher Education Consortium, The Institute for Higher Education Policy, Tribal Colleges, An Introduction (Feb. 1999): A-2, B-2.

31. Helene Whitson, "Introductory Essay," in The San Francisco State College Strike. Available online from http://www.library.sfsu.edu/strike/.

32. Alexander W. Astin, Minorities in Higher Education (San Francisco: Jossey-Bass, 1982), quoted in Delores P. Aldridge and Carlene Young, Out of the Revolution: The Development of Africana Studies (Lanham, Md.: Lexington Books, 2000), 6. 
late 1960s and early 1970s, programs in black studies, Chicano studies, Asian-American studies, and Native-American studies proliferated.

Along with developing these new curricula, colleges and universities "poured money and other resources into the development of the library and archival collections they needed in order to support them." ${ }^{33}$ Some only acquired contemporary books and journals, but others developed major holdings of primary source material. In the field of Chicano studies, Stanford University began collecting the papers of Chicano leaders in the 1970s; and in 1974, the University of Texas at Austin established a Mexican-American Library Program within the Benson Collection, which includes among its holdings the papers of the League of United Latin American Citizens (LULAC). The Colección Tloque Nahuaque at the University of California at Santa Barbara, founded in 1971, broadened its archives program in 1988 to create the California Ethnic and Multicultural Archives (CEMA), administered through Special Collections. ${ }^{34}$ An in-depth examination of the many ethnic collections formed in the wake of the civil rights movement is beyond the scope of this article, but such a study in combination with recommendations for building new ethnic collections is urged as a follow-up article for $R B M$.

During the years of segregation, most African American librarians trained at either Hampton Institute (1925-1940), Atlanta University (1941present; now Clark Atlanta University), or North Carolina Central University (1941-present), in preparation for work in black communities. ${ }^{35}$ Very few Hispanics, Asian Americans, or Native Americans pursued librarianship as a career. As the 1960s brought issues of race and ethnicity

33. Stanton F. Biddle and Verdia Jenkins, "Developing Ethnic Archives," in Ethnic Collections in Libraries, ed. E. J. Josey and Marva L. DeLoach (New York: Neal-Schuman, 1983), 286. 34. Salvador Güereña, "Archives and Manuscripts: Historic Antecedents to Contemporary Chicano Collections," California Ethnic and Multicultural Archives, University of California, Santa Barbara (1999), 8-10. Available online http://cemaweb.library.ucsb.edu/arcman.html.

35. E. J. Josey, 1998 Josey Speech, California Librarians Black Caucus. Available online from http:// www.clbc.org/josey_speech.html. 
to the forefront, concerned librarians from underrepresented groups turned their attention to the issue of minority recruitment. In 1968, California State University founded the Graduate Institute for Mexican American Librarians; and in 1972, the University of Arizona launched its Graduate Library Institute for Spanish-Speaking Americans (GLISA). ${ }^{36}$

Library schools continue to struggle to attract students of color, and some of the schools that have been most successful in doing so are struggling to remain open. The 2002 Statistical Report produced by the Association for Library and Information Science Education indicates that 70 percent of library school graduates are white, 5 percent are black, 2.5 percent are Hispanic, 3 percent are Asian, and 0.5 percent are Native American, with international students making up the rest. ${ }^{37}$ This past year, the administration of the University of Arizona considered closing the School of Information Resources and Library Science but was persuaded not to, in part because of the success of its Knowledge River program for Hispanic and Native American students. ${ }^{38}$ Clark Atlanta University is considering closing its School of Library and Information Studies, which has been historically critical to the education of African-American librarians, due to the university's current budgetary crisis. ${ }^{39}$

Inspired by the social movements of the 1960s, librarians from underrepresented racial and ethnic groups began forming their own organizations outside the mainstream of the ALA, which they felt was too unresponsive to their needs. ${ }^{40}$ Although never a segregated organization, the ALA took a great amount of heat in 1936 for holding a confer-

36. Tami Echavarria and Andrew B. Wertheimer, "Surveying the Role of Ethnic-American Library Associations," Library Trends 46, no. 2 (Fall 1997): 6.

37. Jerry D. Saye and Katherine M. Wisser, "Students," Library and Information Science Education Statistical Report 2002, Association of Library and Information Science Education. Available online from http://ils.unc.edu/ALISE/2002/Students/Students01.htm.

38. "University of Arizona SIRLS Spared from Elimination!" Breaking News, Library Journal, April 14, 2003. Available online from http://libraryjournal.reviewsnews.com/.

39. Bobby Player, Sr., "Announcements," Black Caucus of the ALA. Available online from http:// www.bcala.org/announcements/about.htm.

40. Echavarria and Wertheimer, "Surveying the Role," 2-4. 
ence in Richmond, Virginia, where black attendees were required to sit in a separate section of the meeting hall, were not allowed to attend any sessions where meals were served, and could not stay in the conference hotels used by whites. The following year, the ALA passed a resolution stating that all members "must be admitted under terms of full equality" to halls used by the organization, but a precedent had been set. ${ }^{41}$

In the 1960s, the ALA was criticized for failing to take a stand against segregation in libraries. In 1960, an angry librarian wrote in Library Journal: "The American Library Association has been completely ineffective about this issue. It has never even passed a resolution on the subject ... Why can't ALA just come out and say it stands foursquare for integrated libraries? A mere statement is better than nothing." ${ }^{42}$ Although the ALA amended the Library Bill of Rights in 1961 to support equal access to libraries for all, the organization refused to come to the assistance of members who were fighting segregation in their own libraries. ${ }^{43}$ The feeling that the ALA did not support the needs or interests of librarians from underrepresented groups contributed to the formation of separate racially and ethnically based professional organizations.

The following ethnic associations and caucuses all had their starts during the 1970s: the Black Caucus of the American Library Association (BCALA), 1970; REFORMA, the National Association to Promote Library Services to the Spanish Speaking, 1971; the two precursors to the Chinese American Librarians Association (CALA), 1973 and 1974; the discussion group that led to the Asian/Pacific American Librarians Association (APALA), 1975; and the American Indian Library Association (AILA), $1979 .{ }^{44}$ As Mengxioung Liu, former president of CALA,

\footnotetext{
41. Rosemary Ruhig Du Mont, "Race in American Librarianship: Attitudes of the Library Profession," Journal of Library History 21, no. 3 (Summer 1986): 488, 494-96.

42. Rice Estes, "Segregated Libraries," Library Journal 85 (1960): 4419-20.

43. Du Mont, "Race in American Librarianship," 503-4.

44. Echavarria and Wertheimer, "Surveying the Role," 2.
} 
recalled in 1997, "There was a need to enhance communication among Chinese-American librarians to discuss the common concerns in providing service to Chinese-American populations, and to promote career advancement for Chinese-American librarians.”45

\section{The Lack of Diversity in RBMS}

In 1954, the Association of College and Research Libraries formed a Committee on Rare Books, Manuscripts, and Special Collections; and in 1958, the ACRL Board of Directors voted formally to establish a Rare Books Section within the division. "The formation of a professional membership organization to meet education and communication needs reflect[ed] the dramatic rise in the number of rare book, manuscript, and special collections departments in university libraries during the 1940s and 1950s." With so many rare book librarians coming from the white male-dominated antiquarian book trade, it is no surprise that the membership of the new section was solidly white and its leadership heavily male.

Although chairs of the earlier ACRL committee had included Georgia Haugh and RBMS cofounder Marjorie Wynne, RBMS itself appointed no female chairs during the 1960s and only three female chairs during the 1970s. ${ }^{47}$ Alice Schreyer of the University of Chicago recalls the organization being fairly mixed by gender and collegial by the late 1970 s but agrees that women desired greater representation at the top. "It was not only the perception but the reality of the old boys' network, with many people having connections who were coming out of the book trade in the fifties and sixties." 48

45. Mengxious Liu, personal communication with Echavarria and Wertheimer, March 28, 1977, quoted in Echavarria and Wertheimer, "Surveying the Role," 4.

46. Alice Schreyer, "RBMS at 30: Growing Along with the Profession," Rare Books and Manuscripts Librarianship 3, no. 1 (Spring 1988): 3-4.

47. Ibid., 1,17 .

48. Alice Schreyer (director, Special Collections Research Center, University of Chicago), interviewed by the author, August 8, 2003. 
Several people interviewed for this article pointed to the 1980s as a period of great change for RBMS. During the 1980s, those serving as chair of RBMS were split equally between men and women for the first time. According to Marvin Taylor of New York University, a younger group of gay and lesbian librarians became active in the section, fostering increased openness within the section about issues of sexual preference. ${ }^{49}$ And in the late 1980s, the expansion of the literary canon and the richness of ethnic collections were addressed in preconference sessions.

But as these changes were taking place, little was happening to encourage racial and ethnic diversity among the RBMS membership. Some members recall the section's lack of diversity being discussed as a problem, but never in a formal way. "Diversity was always on the table," according to Daniel Traister of the University of Pennsylvania. "Nobody was unaware of it." 50 "It never went unremarked," agrees Taylor, "but people didn't know how to approach it. Everyone wanted to do something, but didn't know how." All five members interviewed for this article agree that there has been no overt resistance to changing the status quo. Most would agree with Peter Hanff of the University of California at Berkeley that "we would all welcome people from different backgrounds." 51

And yet there is certainly room for criticism of the section for recognizing such a significant problem year after year and failing to address it. "Given the fact that ours is inherently a conservative profession, they were slow to move," says Taylor. "A lot of people go into this profession because they like the idea of old books, port, and paneled rooms." Preoccupied

49. Marvin Taylor (director, Fales Library and Special Collections, New York University), interviewed by the author, August 4, 2003. All subsequent quotes by Taylor are from the same interview.

50. Daniel Traister (curator of Research Services, Annenberg Rare Book and Manuscript Library, University of Pennsylvania), interviewed by the author, July 25, 2003. All subsequent quotes by Traister are from the same interview.

51. Peter Hanff (deputy director, Bancroft Library, University of California, Berkeley), interviewed by the author, July 18, 2003. All subsequent quotes by Hanff are from the same interview. 
with issues of funding, preservation needs, changing technology, and outreach, people threw up their hands at the challenge of diversity.

Theresa Salazar of the University of California at Berkeley is one of the few librarians of color who has regularly attended RBMS preconferences over the years and taken an active role in the section. A Hispanic woman originally from New Mexico, Salazar was drawn to special collections librarianship because of her background in art history and interest in original materials. She admits to having had feelings of selfconsciousness when first participating in professional activities. "Part of it," she says, "is seeing myself as an anomaly ... perceiving myself as an outsider to that world. You're looking for common ground, and there is that in the interest, but there isn't that in the background." 52

The major activity of the section is the preconference, which takes place immediately before the ALA annual meeting. Since 1961, the preconference has occurred every year on a topic or topics of interest to special collections librarians and their colleagues in the rare book world (the least inclusive of these being 1966's unfortunately titled "Men and Books: The Interdependence of Collectors, Rare Books, Librarians and Booksellers"). ${ }^{53}$ Looking back at preconference programs for the past twenty years, it is clear that numerous sessions, seminars, papers, and tours have been held on ethnic collections, particularly when the preconference itself was in a location known for its ethnic diversity.

The 1989 preconference in Dallas, Texas, "Local History, Global Village: Regional Collecting, Regional Collections" featured a program on Hispanic collections by Cesar Caballero of the University of Texas at El Paso and one on the records of the Civil Rights Movement by Dan Den

52. Theresa Salazar (curator of the Bancroft Collection of Western Americana, University of California, Berkeley), interviewed by the author, August 6, 2003. All subsequent quotes by Salazar are from the same interview.

53. Schreyer, "RBMS at 30," 11. 
Bleyker of the Mississippi Department of Archives and History. In 1994, the preconference "From Collector to Donor: Building Special Collections with Private Passions" was held in Miami Beach, Florida, and featured Elinor Des Varney Sinnette, the biographer of Arthur Schomburg.

In 1995, a preconference was organized in Bloomington, Indiana, on the theme "Collecting Cultures: The Politics and Practice of Building Special Collections." Program chair Marvin Taylor recounts, "The idea behind it was that we have traditionally been an organization that was Anglophilic, and we had been missing many opportunities. We needed to follow scholarship where it was going. We were not paying enough attention to documenting other cultures, even those that were important to the development of our own history." At the preconference, Eugene Eoyang of Indiana University spoke on "Neglected Ancestors: Bilingual Pioneers in U.S. History" and panelist Cathy M'Closky of York University (Canada) discussed Navajo weaving and the papers of Southwestern trader Lorenzo Hubbell. Other panelists addressed gay and lesbian studies, women's studies, and popular culture. "This conference was blasted for being politically correct," Taylor says. "Though a lot of people really enjoyed it, there were also a lot of scathing reviews ... People thought I was pandering to the current trends."

An occasional tour or session focused on ethnic collections appeared at preconferences through the 1990s. But in 2002, program chair Nora Quinlan took advantage of the preconference location of Atlanta truly to showcase the issue of diversity as part of "New Occasions, New Duties: Changing Roles and Expectations in Special Collections." Michael Lomax, president of Dillard University, an HBCU in New Orleans, gave a plenary session on "Finding African-American Voices." Seminars included one on "Collecting Rare Afro-Americana," moderated by Randall Burkett at Emory and featuring local collectors and a roundtable discussion titled "A Dialogue on Diversity: Issues Raised by 
the RBMS Non-Member Survey." The Auburn Avenue Research Library on African-American Culture and History and the Martin Luther King Jr. National Historic Site were options for a combined walking tour.

The location, cost, and length of the preconference may discourage some librarians from underrepresented groups from attending. Preconferences tend to be held in the eastern half of the United States; in the past twenty years only four have been held in the far West, all in California. ${ }^{54}$ Registration for the preconference is typically $\$ 195$ for ACRL members and $\$ 250$ for nonmembers, and the three-day event requires a significant financial outlay for accommodations and meals. Hanff agrees that, "By doing [the conferences] the way we do, we limit access to them." RBMS should consider making changes to the preconference, such as offering one-day registrations to allow more librarians from underfunded institutions to attend.

Another major activity of section members is editing RBM: A Journal of Rare Books, Manuscripts, and Cultural Heritage (formerly known as Rare Books and Manuscript Librarianship, or RBML), which is published by ACRL. In its first incarnation, $R B M L$ described itself as devoted to "the theory and practice of special collections librarianship." ${ }^{25}$ Since its debut in 1986, neither $R B M$ nor $R B M L$ has ever published a single article on racial and ethnic diversity or ethnic collections, despite awareness of the lack of diversity in the section and the occurrence of preconference sessions on ethnic collections. Several articles in the late 1980s addressed the issue of the expansion of the literary canon and the new interest in social history, touching briefly on the growing interest in ethnic collections: Daniel Traister's "What Good is a Rare Book?" and Michael Winship's "New Ranges for Old Pastures: Bibliographies of Western Americana."

54. RBMS Conference Development Committee, RBMS Preconference Planning Manual. Available online from http://www.nova.edu/library/cdc/cdc.manual.htm.

55. "Guidelines for Submission of Articles to Rare Books and Manuscripts Librarianship," Rare Books and Manuscripts Librarianship 3, no. 1 (Spring 1988): 82. 
In all fairness, $R B M L$ and $R B M$ have always published more articles on the practice of special collections librarianship than on the content of collections. And Alice Schreyer (RBML editor, 1989-1993) explains that it was difficult to solicit articles for the journal, and many preconference speakers were not interested in revising their talks for publication. But she also admits that "when we thought about topics pertinent to our work, ethnic collections did not come to mind; but if it had, I'm not sure we would have been successful getting someone to write about it." ${ }^{56}$ Marvin Taylor (RBM coeditor, 2000-2003) says that the editorial board discussed devoting an entire issue to the topic of diversity and that they passed along the suggestion to current editor Richard Clement. But in the professional journal as well as in recruitment to the organization, it is undeniable that RBMS has again been "slow to move."

RBMS needs to make a greater effort to be more welcoming to members from underrepresented racial and ethnic groups and to understand that if we continue to be passive on the issue of diversity, we will continue to be a homogeneous organization that does not reflect the makeup of our society or support the interests of those we serve. Salazar recalls an episode from the mid-1990s. The Membership Committee wanted to address the problem of new members feeling that they were not being integrated into RBMS because of already established cliques. Some older RBMS members protested that they personally were always open to new members when approached, but Salazar points out that it is important "that we not always put the expectation on the newcomers." She believes that the same attitude that led to creation of the Buddy Program (which pairs first-time preconference or conference attendees with more experienced members) is needed for encouraging diversity in the section. "I think there has to be more initiative. They're not going to raise their hands and come to you ... there has to be more of a courting of that group." 
But creating a more responsive culture in RBMS will not in itself attract enough diverse librarians to the section. As RBMS members point out, few nonwhites enter the field of librarianship, and of those who do, even fewer specialize in rare books, manuscripts, and archives. As Schreyer puts it, "The problem is we're not attracting them to the profession, not that we're not moving them through." 57 Traister, a university instructor as well as a librarian, says, "There's still an enormous amount of basic bigotry out there, but I don't think that's the only problem. Part of the issue is attracting people to the low-paying field of librarianship." As an advisor to undergraduates, Traister sees many students choosing careers based on possible earnings rather than on academic interests. "Finding students who are going to go on in the humanities broadly conceived, let alone the bibliographical areas; ... the salaries suck." And Taylor points to the elitist stereotype of the profession as an issue. "This isn't going to be the kind of environment that is going to be welcoming to other cultures unless they want to play into the Ralph Lauren, English book-collecting lifestyle."

Members did suggest that ethnic collections might be an avenue for attracting more people from underrepresented racial and ethnic groups to special collections librarianship. Traister says, "One of the things that I do see happening is a growing African American collecting community." He hopes that this growth will lead to more situations where an African American becomes the librarian for a private collection and then moves to an institution with the collection to serve as its curator. Salazar agrees that many curators from underrepresented groups are attached to particular collections: "They're specialists in those areas, and fill an important niche in their institutions. In some ways those [professional] positions came about because of the need to create those specialized collections."

57. Schreyer interview, August 8, 2003. 
Hanff underlines the valuable contribution that can be made by a librarian or archivist who has a strong background in the culture being documented. "Wherever we have these collections, we are well-served with people who can understand the nuances of the content with great knowledge." Salazar agrees, but also points out that "one of the other places where that has to be addressed is in library schools, where someone might be encouraged to take a course in archives or bibliographic description."

\section{The Path toward Diversity in RBMS}

In the spring of 1997, the Membership Committee placed a survey for RBMS members in the section's newsletter. The survey was funded by an ACRL Initiative Grant. It asked questions about the members' age, race, and ethnicity; their educational and professional background; and their involvement with RBMS and other organizations. It was thought that such information would help with future planning for the section and could shed light on the current state of the profession. ${ }^{58}$

Of the 1,842 surveys that were mailed out in the RBMS newsletter, 221 were returned. Of these respondents, 97 percent indicated that they were white. Of the nonwhite members, 1.5 percent were black, 1 percent were Hispanic, 0.5 percent were Asian or Pacific Islander, and none were Native American or Alaskan Native. Sixty-six percent of the members lived either in the Northeast, the Midwest, or the Mid-Atlantic States. Over half of them worked in special collections full-time, 58 percent of them worked in libraries of one million volumes or more, and almost half worked in departments with more than 100,000 volumes. ${ }^{59}$ At the 2000 preconference in Chicago, the Membership Committee presented the results of the survey; astonishingly, no one present at the seminar (including this author) brought up the lack of racial and ethnic diversity.

58. Brad Oftelie, "Results of the 1997 Membership Survey of the Rare Books and Manuscripts Section (RBMS), Association of College and Research Libraries, American Library Association," 1999. 59. Completed "RBMS Membership Survey" forms held by RBMS Membership and Professional Development Committee. 
In June 2000, a second survey, also funded by ACRL, was sent out to target special collections and archives professionals who were not currently members of RBMS. According to Suzy Taraba of Wesleyan University (Membership Committee chair, 1994-2000), the committee "wanted to know why some special collections librarians were not RBMS members, and to reach out to them. The non-member survey was always seen as both a survey and a recruitment tool." ${ }^{60}$ The survey was mailed to institutions with predominantly black, Hispanic, or Native American enrollment, and addressed to the special collections librarian or archivist. ${ }^{61}$ The response rate was not as high as that of the previous surveyof the 230 surveys that were sent out, 41 were returned-so there is a higher margin of error with this survey. ${ }^{62}$

Of the librarians or archivists at predominantly minority institutions who responded, 41 percent were white. Another 27 percent each were black or Hispanic, with American Indian or Alaskan Native librarians making up the other 5 percent. Unlike the RBMS members, 67 percent of the nonmember group lived either in the South or Southwest. Only 22 percent of them worked in special collections full-time, 72 percent worked in small libraries with fewer than 250,000 volumes, and their special collections held fewer than 10,000 volumes. ${ }^{63}$

Half of the librarians in the nonmember survey were unfamiliar with RBMS, and several felt that their needs were better served by other organizations. Many of them were members of the Society of American Archivists or of regional and state organizations. ${ }^{64}$ As Salazar says, “[RBMS] isn't necessarily these folks' first choice because other organiza-

60. Suzy Taraba, chair, RBMS Membership Committee (1994-2000), interviewed by the author, Spring 2002.

61. Isaac Gewirtz, member, RBMS Membership Committee (1995-2000), interviewed by the author, Spring 2002.

62. Completed "Survey of Special Collections Librarians and Archivists Who are Not Members of RBMS" forms held by RBMS Membership and Professional Development Committee.

63. Ibid

64. Ibid. 
tions may more directly address their concerns. They're tied in already to these other organizations, and the funding is a big issue." Indeed, a third of the librarians surveyed received $\$ 200$ or less a year toward conference attendance. Their comments on the survey form reflect that: "No financial support from college," "Costs are always a factor," and "I attended two conferences last year ... far too expensive." ${ }^{\prime 65}$

The results of the nonmember survey were presented at the 2002 preconference in Atlanta as an introduction to a roundtable discussion on diversity that featured six library and archives professionals from underrepresented racial and ethnic groups. The panelists included Alma Dawson, a library science professor at Louisiana State University who had served as chair of the ACRL Committee on Racial and Ethnic Diversity from 1995 to 1997; Adán Griego, the curator for Latin American, Mexican American \& Iberian Collections at Stanford University and a participant in the Seminar on the Acquisition of Latin American Materials (SALALM); Brenda S. Banks, deputy director for the State Archives of Georgia and former chair of the Society of American Archivists' Task Force on Diversity; Cathy Lu, a librarian at the Chinatown Branch of the Los Angeles Public Library who is also a member of the Asian/Pacific American Librarians Association (APALA); Stacy Swazy, a 2001 graduate from Clark Atlanta University who works as a processing archivist at the Atlanta University Center Archives; and Elizabeth Robinson, the rare book team leader at the Library of Congress and a longtime RBMS member.

Dawson spoke about efforts to increase diversity in ACRL and encouraged RBMS members to take advantage of diversity resources that already existed and to use promotional tools such as brochures to reach out to communities. Banks described the final report of the SAA Task Force on Diversity, remarking that its four recommendations were 
"easily achievable because they didn't cost anything." ${ }^{66}$ Robinson gave her perspective as an African American woman active in RBMS, explaining that she had not felt uncomfortable joining RBMS because of her previous work experiences in largely white environments. And recent graduate Swazy described the love for history that had led her from a corporate job to library school and now a career in archives.

On the heels of the seminar, there was a growing sense that RBMS needed to create its own action plan just as these other organizations had done. This was the first time we had looked outside ourselves to see how our parent organizations, ALA and ACRL, and the most similar organization to us, SAA, were managing diversity. In looking to our parent organizations, we also wanted to learn what programs they already had set up that we could utilize in order to achieve greater diversity.

Since 1998, ALA has managed its diversity efforts through the Office for Diversity, ${ }^{67}$ which serves as the liaison to the ALA Committee on Diversity and its subcommittees and administers the Spectrum Initiative. The Committee on Diversity has a broad charge that includes encouraging diversity in ALA's membership and the recruitment and retention of a diverse library workforce. The committee has two subcommittees: the Diversity Council, which is composed of representatives from the five ALA ethnic caucuses and the Gay, Lesbian, and Transgendered Round Table; and the Spectrum Advisory Council. ${ }^{68}$

Established in 1998, the Spectrum Initiative is ALA's national effort to recruit people from underrepresented groups for careers in librarianship, primarily through the provision of scholarships that award $\$ 5,000$ toward

66. Notes taken by Deborah J. Leslie, "A Dialogue on Diversity: Issues Raised by the RBMS NonMember Survey" seminar, 43rd Annual RBMS Preconference, Atlanta, June 13, 2002.

67. Sandra Rios Balderrama, "Diversity Officer Says Farewell," American Libraries 33, no. 8 (September 2002): 11.

68. Office for Diversity, ALA. Available online from http://www.ala.org/Content/NavigationMenu/ Our_Association/Offices/Diversity3/Diversity.htm. 
graduate school in library and information science. ${ }^{69}$ So far, more than 250

Spectrum scholarships have been awarded. Spectrum scholars participate in a three- to four-day leadership institute as part of the award and may also find themselves the recipients of matching scholarships, internships, and other opportunities due to their participation in the program. ${ }^{70}$

In 1990, the ACRL Task Force on Recruitment of Underrepresented Minorities presented a report to the ACRL board. That same year, ACRL established a Racial and Ethnic Diversity Committee, and the following year ACRL issued a statement on diversity. Since then, the committee has sponsored numerous conference programs, conducted surveys, and developed a Web site of diversity resources. In 1997, the committee presented the report Recruiting the Underrepresented to Academic Libraries: Challenges and Opportunities, which assessed the recommendations of the previous task force in light of the division's new strategic plan. The report recommended initiatives such as establishing a mentoring program, collecting data on the participation of underrepresented groups in ACRL and ALA, training academic librarians in ethnic and cultural awareness, and appointing liaisons from the Racial and Ethnic Diversity Committee to other ACRL and ALA committees. ${ }^{71}$

The Society of American Archivists has been much more proactive in addressing diversity issues than has RBMS. In 1999, SAA issued a statement on diversity, which is posted on its Web site. ${ }^{72}$ Since 1987 , SAA has sponsored an Archivists \& Archives of Color Round Table

\footnotetext{
69. "Spectrum Initiative-New Faces, New Era," Office for Diversity, ALA. Available online from http://www.ala.org/Content/NavigationMenu/Our_Association/Offices/Diversity3/ Spectrum_Initiative/Spectrum_Initiative.htm.

70. "Spectrum Initiative-Spectrum Scholar Information," Office for Diversity, ALA. Available online from http://www.ala.org/Content/NavigationMenu/Our_Association/Offices/Diversity3/ Spectrum_Initiative/The_Spectrum_Scholars/The_Spectrum_Scholars.htm.

71. ACRL Racial and Ethnic Diversity Committee, Recruiting the Underrepresented to Academic Libraries: Challenges and Opportunities, 1997; also ACRL Racial and Ethnic Diversity Committee. Available online from http://www.ala.org/Content/NavigationMenu/ACRL/About_ACRL Committees,_Task_Forces, _and_Discussion_Groups/ACRL_Racial_and_Ethnic_Diversity_Committee_.htm.

72. Society of American Archivists, Position Statement on Diversity. Available online from http:// www.archivists.org/statements/diversitystatement.asp.
} 
which is very active, organizing sessions and publishing a newsletter. ${ }^{73}$ Recently, the roundtable has added a Directory of Archivists of Color to its Web site. ${ }^{74}$ For the 2003 annual meeting in Los Angeles, the roundtable sponsored seven sessions and three tours dealing with diversity issues and diverse collections. ${ }^{75}$

In 1997, SAA established a Task Force on Diversity, which delivered its final report in 1999. Its recommendations included issuing an SAA position statement on diversity, incorporating diversity into the SAA strategic planning process and reinforcing and expanding activities such as mentoring and developing programs on diversity topics. New initiatives included enhancing the Web site, adding a diversity fair to the annual meeting, increasing scholarship aid, gathering data, and encouraging internships in archives for high school and college students and for community representatives from underrepresented groups. ${ }^{76}$ We should remember that the work of implementing diversity initiatives must not end with completion of the report. In the fall/winter 2002 Archivists \& Archives of Color Newsletter, Rebecca Hankins wrote, "A few years ago SAA gave lip service to diversity and organized a taskforce to investigate and survey the state of the organization and offer recommendations. That report, by all accounts, has become a part of SAA's "archival backlog."77

In August 2002, the RBMS executive committee approved a Statement on Diversity, which can be found on the RBMS Web site at http:// www.rbms.nd.edu/. The executive committee also appointed a Task

73. Archivists \& Archives of Color Roundtable, "Our Mission," Society of American Archivists. Available online from http://www.archivists.org/saagroups/aac/mission.htm.

74. Archivists \& Archives of Color Roundtable, Archivists of Color Directory 2002, 3rd ed, Society of American Archivists. Available online from http://www.archivists.org/saagroups/aac/

Members_alphadirectory.htm.

75. Archivists \& Archives of Color Roundtable, "Announcements," Society of American Archivists. Available online from http://www.archivists.org/saagroups/aac/Announcements.htm.

76. Task Force on Diversity, Final Report to SAACouncil, Feb. 1999. Available online from http:// www.archivists.org/governance/taskforces/diversity_final.asp.

77. Rebecca Hankins, "From Exclusive to Inclusive?" Archivists \& Archives of Color Newsletter 16, no. 2 (Fall/Winter 2002): 2. 
Force on Diversity, with Julie Grob of the University of Houston as its chair. Members included Caroline Duroselle-Melish of the University of Rochester (now at Harvard University), James Fox of the University of Oregon, Adán Griego of Stanford University, and Suzy Taraba of Wesleyan University.

Charged with creating an action plan for encouraging diversity in the section, our task force studied a number of action plans from other organizations and universities. Each member was assigned responsibility for one of six topics-scholarships, mentoring, publicity, outreach, liaison relationships, and collections - and asked to generate a list of related ideas for encouraging diversity. At the 2003 midwinter meeting in Philadelphia, we used a group process technique called Multivoting to edit the list down quickly as a group. We invited all meeting guests who were current members of RBMS to participate.

We knew that it would be critical to the success of the diversity initiative to select ideas that were practical enough that they would actually get implemented. Neither SAA nor ACRL was able to achieve all of the goals expressed in its ambitious action plans. Because RBMS had so much work ahead of it in encouraging diversity, it made sense to start with actions that would be relatively easy to carry out, yet could potentially have a strong impact on the organization. We used a different process tool called an Ease/Impact Model to further sort our ideas by e-mail, screening out those that would be too cumbersome or have limited impact.

At this point, inspired by some of the other organizations' action plans, we reoriented our plan around a set of goals. Four out of the five goals that we delineated came directly from the wording of our task force's charge:

1. To encourage librarians of various backgrounds, particularly underrepresented racial and ethnic groups, to join RBMS; 
2. To promote special collections librarianship as a career to member of underrepresented racial and ethnic groups;

3. To liaise and pursue initiatives with other groups that focus on diversity or diverse collections;

4. To encourage special collections in collecting materials from diverse communities; and

5. To promote diversity as a value to RBMS members.

Our final task was to do a "reality check" for each item. For each strategic item in the Diversity Action Plan, a task force member contacted people who could provide perspective on the feasibility of the idea. For example, in considering the brochure idea, we contacted the chair of the Publicity Committee and learned about financial limitations due to the recent overhaul of the RBMS brochure. The people we contacted gave us support for some ideas, steered us away from others, and made suggestions on how ideas could be practically implemented.

In creating the Diversity Action Plan itself, our goal was to give information that would clearly explain why an action should be taken and how it should be carried out. We also decided to designate a responsible party who would ensure that the action would be accomplished. In this way, we hoped to eliminate potential roadblocks to the implementation of the action plan. The following version of the Diversity Action Plan lists only the strategic action itself and its rationale; a full version of the plan including the implementation and responsible party sections can be found online at http://www.rbms.nd.edu/.

RBMS Diversity Action Plan

Approved by the RBMS Executive Committee, June 23, 2003

Goal 1. To encourage librarians of various backgrounds, particularly underrepresented racial and ethnic groups, to join RBMS 
Strategic Actions:

A. Offer Preconference scholarships to librarians from underrepresented racial and ethnic groups

Rationale: Librarians from underrepresented racial and ethnic groups who work with special collections materials may be interested in RBMS activities but hesitant to attend a first RBMS preconference for financial reasons. A scholarship would give some of these librarians the opportunity to attend a preconference and could potentially lead them to become members and full participants in RBMS. Specifying one scholarship as being geared to librarians from underrepresented groups might encourage such a professional to apply and would reinforce the public perception of RBMS's commitment to diversity.

B. Expand buddy program to include mentoring for new members from underrepresented racial and ethnic groups

Rationale: The RBMS Buddy Program, which pairs new members with more experienced members, is intended to make preconference and other meetings less daunting for new members in hopes that this will encourage them to remain active in the section. Because RBMS may seem particularly intimidating to a new member from an underrepresented racial or ethnic group, a mentoring program should be set up for these members.

This program would also pair an experienced RBMS member with a new member at the annual preconference or ALA meeting, but the relationship would formally last for a year or two rather than ending after that meeting.

C. Revise introductory membership materials to mention underrepresented groups 
Rationale: Many people have their first encounter with RBMS through introductory materials such as the RBMS brochure and the membership section of the RBMS Web site. These points of entry to the organization are places where RBMS can communicate its commitment to diversity and reach potential members with the message that RBMS is inclusive. Both the RBMS brochure and the Web site should be revised to incorporate the notion of a diverse membership and support for diverse collections.

\section{Create brochure targeted to underrepresented groups}

Rationale: A brochure targeted to underrepresented groups could give information about RBMS's commitment to encouraging diversity among its membership, the section's encouragement of diverse collecting by its members at their own institutions, and the section's interest in forging relationships with special collections professionals and community members from underrepresented groups. It could serve as a tool for outreach to library school students, educators, librarians, archivists, and community members, describing both the mission of RBMS and the work of special collections librarians and archivists. The brochure could promote RBMS as an inclusive organization that exists to serve the needs of all special collections professionals and could promote special collections as a means for preserving the distinct history and culture of diverse groups.

Note: Because of the very recent revision of the RBMS brochure, this action will first be pursued as a one-page insert.

\section{Goal 2. To promote Special Collections librarianship as a career to members of underrepresented racial and ethnic groups}

Strategic Actions:

\section{A. Offer preconference scholarships to students from underrepresented racial and ethnic groups}


Rationale: Special collections librarianship remains a field elected by few library school students from underrepresented racial and ethnic groups. A student who is considering specializing in this branch of the profession might be encouraged to do so by attending an RBMS preconference. Having a scholarship geared to applicants from underrepresented groups might encourage such a student to apply and would reinforce the public perception of RBMS's commitment to diversity.

B. Hold presentations on special collections at heavy minority enrollment institutions in cities where RBMS preconference or ALA conferences are held Rationale: RBMS could take advantage of the opportunity afforded by the changing locations of the preconference and ALA conferences to reach out to students in different cities across North America. These presentations would create an awareness of special collections materials among students from underrepresented groups and would introduce them to the idea of special collections librarianship as a potential career choice. They would also help present RBMS to nonmembers as an organization that values diversity.

\section{Goal 3. To liaise and pursue initiatives with other groups that focus on diversity or diverse collections}

Strategic Actions:

\section{A. Liaise and pursue initiatives with ACRL Committee on Racial and Ethnic Diversity}

Rationale: As a section within a larger division and a larger association, RBMS should take advantage of the structures that already exist in the parent organization for fostering diversity. Making contacts within existing committees and offices, and letting other members of the organization know about our interest in diversity, are steps that may lead to new opportunities for encouraging diversity within RBMS. 
B. Liaise and pursue initiatives with ALA Office for Diversity

Rationale: Same as above.

\section{Liaise and pursue initiatives with ALA Spectrum Initiative}

Rationale: The Spectrum Initiative is a significant effort by ALA to develop a representative workforce primarily by awarding scholarships to members of underrepresented racial and ethnic groups. Some of the previous Spectrum scholars have had student jobs or a special interest in special collections or archives. RBMS members should make themselves available to these future library professionals.

\section{Goal 4. To encourage special collections in collecting materi- als from diverse communities}

Strategic Actions:

A. Hold a workshop or conference program on how to approach relevant community organizations and faculty and begin building culturally diverse collections at your own institution

Rationale: Special collections have a responsibility to reflect both the increasing multiculturalism of our society and the increasing scholarly interest in different cultures when developing our collections. But our individual institutions may not have the historic commitment, cultural knowledge, language skills, and community contacts needed to build diverse collections. A workshop or program on networking with ethnic communities and building culturally diverse collections might encourage RBMS members to initiate more diverse collecting at their own institutions. Such a program could feature examples of library partnerships with community organizations and accounts from librarians who have built culturally diverse collections. 
B. Hold a workshop or conference program on special issues related to culturally diverse collections

Rationale: Collecting materials from culturally diverse communities may be a new area for many in the special collections community. Documenting this multiplicity of voices poses a challenge, as we have to go outside our usual means of collecting. Because of this, a workshop or program on special issues related to collecting these materials would be very useful to RBMS members. Topics might include acquisition outside traditional rare book and manuscript channels, reallocation of resources for acquiring and processing these materials, and the need to collect ephemera (free weeklies, newsletters, etc.) related to different cultural groups.

C. Cosponsor programs on collecting with other ACRL committees or ALA ethnic caucuses

Rationale: RBMS should encourage institutions to collect materials from diverse communities by presenting programs on this topic. As special collections professionals, we need to build connections with colleagues who work primarily with diverse materials or directly serve diverse populations.

RBMS should seek opportunities to cosponsor programs on collecting with the following ACRL sections and ALA ethnic caucuses:

- AFAS (African American Studies Librarians Section), ACRL;

- AAMES (Asian, African, and Middle Eastern Section), ACRL;

- AILA (American Indian Librarians Association);

- APAla (Asian Pacific Librarians Association);

- BCALA (Black Caucus of ALA);

- CALA (Chinese American Librarians Association); and

- REFORMA (National Association to Promote Library and Information Services to Latinos and the Spanish-Speaking. 
D. Urge preconference planning committees to arrange tours to institutions with culturally diverse collections

Rationale: This initiative will benefit both RBMS members and institutions with culturally diverse clientele and collections. RBMS members will benefit by being exposed to potentially new types of collections and by having an opportunity to talk with a culturally diverse group of librarians, archivists, scholars, and readers. The institutions will benefit by the increased exposure of their collections and by the relationships that might be forged between their staff and other librarians from across the country.

Including such institutions among the tour options should become a standardized part of the preconference planning process.

\section{Goal 5. To promote diversity as a value to RBMS members}

Strategic Actions:

A. Hold a workshop or program on what RBMS members can do to help improve diversity in their own corner of the profession

Rationale: As well as furthering diversity in the section, RBMS seeks to encourage individual section members to promote diversity in their own institutions. A workshop or program on such a topic would encourage members to share ideas that have worked for them at their own libraries. Topics might include minority internships, promotion of diverse collections, and community outreach. Such a program might lead to the adoption of some of these ideas at other institutions or the publication of articles on these topics.

B. Submit an article to RBM on the work of the Task Force on Diversity Rationale: One of the primary tasks of the Task Force on Diversity is to encourage people, both members and nonmembers, to perceive RBMS 
as an organization that values diversity. One way that RBMS can do this is by promoting the Task Force on Diversity and the Diversity Action Plan. By letting people know that RBMS has taken initiative in addressing the section's lack of diversity, we may begin to decrease perceptions that RBMS does not value diversity.

The publication of such an article would be an excellent way to disseminate the Diversity Action Plan and to let people know about opportunities for participation and collaboration on diversity initiatives.

\section{The Future of Diversity in RBMS}

Following approval of the Diversity Action Plan, the RBMS executive committee formed a Diversity Action Plan Implementation Task Force composed of Carolyn Coates of Eastern Connecticut State University, Adán Griego of Stanford University, Julie Grob of the University of Houston (chair), Hjordis Halvorson of the Newberry Library, and J. Fernando Peña of the Grolier Club. The task force will coordinate with the various committees of RBMS in the implementation of the parts of the action plan for which they are responsible and implement any actions that fall outside the charge of an existing committee.

Achieving greater diversity will be a challenge for RBMS, because of both historical factors such as the traditional Anglo-American focus of rare book and manuscript collections and current realities such as the low numbers of students from underrepresented racial and ethnic groups entering the profession. The best way for RBMS to encourage change is by taking action to address these challenges and seek to move beyond them, becoming a more diverse organization. The Diversity Action Plan can be an effective tool for making this happen, but ultimately it is only a piece of paper. It will require the energy, creativity, and goodwill of RBMS members to turn this piece of paper into a vital and inclusive reality. 